\title{
PERANAN BADAN NARKOTIKA NASINOAL (BNN) DALAM MENEGAKKAN HUKUM TERHADAP PELAKU TINDAK PIDANA NARKOTIKA (STUDI DI BADAN NARKOTIKA NASIONAL KABUPATEN TAPANULI SELATAN)
}

\author{
Marwan Busyro $^{(1)}$ dan Sutan Siregar ${ }^{(2)}$ \\ ${ }^{(1,2)}$ Dosen Fakultas Hukum Universitas Muhammadiyah Tapanuli Selatan
}

\begin{abstract}
Abstrak
Latar belakang masalah penelitian ini adalah, dimana diketahui bahwa terjadinya tindak pidana narkotika sudah sering kita dengar apalagi dikalangan anak-anak, dewasa dan juga di Negara kita Republik Indonesia dimana kejahatan terhadap narkotika ini sudah merajalela dan juga dapat dikatakan bahwa Negara kita darurat narkotika berdasarkan itulah kiranya penulis tertarik untuk melakukan penelitian terhadap tindak pidana narkotika yang dilihat dari peranan badan Narkotika Nasional (BNN) dalam menegakkan hukum terhadap pelaku tindak pidana narkotika. Lokasi penelitian ini dilakukan di Badan Narkotika Nasional Tapanuli Selatan, tujuan penelitian adalah untuk mengetahui peranan badan narkotika Nasional menjalankan tugas dan fungsinya dalam membantu Penegakan Hukum terhadap penyalahgunaan Narkotika Kabupaten Tapanuli Selatan dan untuk mengetahui hambatan yang dihadapi Badan Narkotika Nasional (BNN) menjalankan tugas dan fungsinya dalam membantu Penegakan hukum terhadap Penyalahgunaan Narkotika di Kabupaten Tapanuli Selatan metode penelitian yang penulis gunakan dalam penulisan penelitian ini adalah penelitian deskriptif yang maksudnya adalah penelitian yang dilakukan dengan hasil wawancara penulis dengan responden dan juga melakukan penelitian terhadap data-data maupun berkas-berkas yang berkaitan dengan penelitian ini dengan cara melakukan Penelitian Lapangan (Library Research) dan Penelitian Kepustakaan (Field Research)
\end{abstract}

Kata Kunci: Badan Narkotika Nasional, Narkotika, Hukum Pidana

\section{Pendahuluan}

Dengan berkembangnya modernisasi pada era pembangunan pada zaman moderen ini, wajarlah jika ingin pembangunan itu terlepas dari segala perbuatan yang dapat merusak kehidupannya, apabila diperhatikan banyak perbuatan yang dilakukan anggota masyarakat yang tidak mendukung ke arah pembangunan bahkan perbuatan itu selain 
tidak mendukung pembangunan sekaligus merusak pembangunan itu sendiri salah satu contohnya adalah perbuatan yang dapat merusak kehidupan manusia yakni penyalahgunaan Narkotika.

Narkotika bukanlah masalah yang baru, dan bukan pula merupakan masalah nasional atau masalah regional saja tetapi merupakan juga masalah global. Sehingga dapat disimpulkan penyalahgunaan Narkotika adalah marupakan patologi sosial internasional, yakni gejala penyakit sosial yang harus diberantas dari muka bumi. Salah satu tujuan negara Indonesia secara konstitusional adalah terwujudnya masyarakat Indonesia yang sejahtera, adil, dan makmur yang merata materiil dan spirituil berdasarkan Pancasila dan Undang-undang Dasar 1945.

Dampak negatif selain kematian, narkoba akan merusak system saraf bagi para penggunanya sehingga tidak jarang para pecandu serimg terganggu pikiran ataupun saraf otaknya, namun dengan ancaman yang akan di rasakan oleh pecandu narkoba, para pecandu kebanyakan tidak menghiraukan hal tersebut yang akan membahayakan keselamatan hidupnya. Mereka malah senang bersahabat dengan benda terlarang terebut, bagi mereka narkoba merupakan sahabat tanpa jiwa yang memiliki kekuatan dalam menolong mereka ketika mereka membutuhkannya. Oleh karena itu kualitas sumber daya manusia Indonesia sebagai salah satu modal pembangunan nasional perlu ditingkatkan secara terus menerus termasuk derajat kesehatannya. Adapun yang dimaksud antara lain tercapainya pertumbuhan ekonomi yang berkualitas dan berkesinambungan sehingga mencapai kesejahteraan; terciptanya peningkatan upaya kesehatan, sarana, dan prasarana, pembiayaan kesehatan, sumber daya manusia kesehatan, pembinaan, pengawasan, pengendalian dan penilaian disertai oleh peningkatan kemandirian masyarakat. Dalam Undang-undang Nomor 35 tahun 2009 tentang Narkotika yang di dalamnya diatur juga sanksi hukumnya, serta hal-hal yang diperbolehkan, maka Badan Narkotika Nasional diharapkan mampu membantu proses penyelesaian perkara terhadap seseorang atau lebih yang telah melakukan tindak pidana narkotika .

Berdasarkan Latarbelakang diatas, maka Peneliti ingin melakukan Penelitian untuk mengetahui sejauh mana peranan Badan Narkotika Nasional dalam penegakan hukum terhadap tindak pidana narkotika serta hambatan-hambatan yang ditemui di dalam pemberantasan tindak pidana Narkotika, dengan judul : Peranan Badan Narkotika Nasional (BNN) Dalam Menegakkan Hukuman Terhadap Pelaku Tindak Pidana Narkotika (Studi di Badan Narkotika Nasional Kabupaten Tapanuli Selatan).

\section{Metode Penelitian}

Sesuai dengan topik dan permasalahan yang dirumuskan dalam penelitian ini maka penulis akan melakukan penelitian di Kantor Badan Narkotika Nasional Kabupaten Tapanuli Selatan yang berada di JL. H. Raja Ianal Siregar Batunadua Padangsidimpuan dengan pertimbangan di Kantor Badan Narkotika Nasional Kabupaten Tapanuli Selatan akan 
mudah dalam mengumpulkan data yang ada kaitannya dengan permasalahan.

Penelitian ini diawali dengan menggunakan pendekatan yuridis normatif, dan emperis sosiologis, kemudian mengkaji penerapannya oleh anggota Badan Narkotika Nasional Kabupaten Tapanuli Selatan menyangkut pertimbangan menjatuhkan pidana terhadap terdakwa sebagai penjual narkotika jenis golongan 1, golongan 2, golongn 3.

Selanjutnya jenis penelitian yang digunakan dalam penelitian ini adalah penelitian normatif dan emperis yang menggunakan sumber data skunder dan berupa peraturan Perundang-undangan,serta Data atau Dokumen Badan Narkotika Nasional terhadap terdakwa sebagai perantara dalam jual beli narkotika golongan I, golongan 2, golongan 3 .

Dalam hal ini apa yang dinyatakan oleh responden, baik secara tertulis maupun secara lisan, diteliti dan dipelajari sebagai bahan utuh. Atas dasar tersebut, maka dapat diperoleh gambaran yang objektif mengenai pertimbangan Untuk menjatuhkan pidana terhadap terdakwa yang melakukan tindak pidana menjual narkotika Golongan 1, Golongan 2, dan Golongan 3.. Hasil analisa data tersebut berupa data yang lebih akurat dan bias dipertanggungjawabkan kemudian selanjutnya dapat ditarik beberapa kesimpulan sebagai hasil akhir.

\section{Pembahasan dan Hasil}

Kedudukan, Tugas Dan Fungsi Badan Narkotika Nasional Kabupaten Tapanuli Selatan Badan Narkotika Nasional
Kabupaten/Kota yang selanjutnya dalamPeraturan Kepala Badan Narkotika Nasional ini disebut BNNK/Kota adalah instansi vertikal Badan Narkotika Nasional yang melaksanakan tugas, fungsi, dan wewenang Badan Narkotika Nasional dalam wilayah Kabupaten/Kota. BNNK/Kota berada di bawah dan bertanggung jawab kepada Kepala BNNP. Dalam melaksanakan tugas sebagaimana dimaksud dalam Pasal23, BNNK/Kota menyelenggarakan fungsi:

a. Pelaksanaan koordinasi penyusunan rencana strategis dan rencana kerja tahunan di bidang P4GN dalam wilayah Kabupaten/Kota;

b. Pelaksanaan kebijakan teknis di bidang pencegahan, pemberdayaan masyarakat, rehabilitasi dan pemberantasan dalam wilayah Kabupaten/Kota;

c. Pelaksanaan layanan hukum dan kerja sama dalam wilayah Kabupaten/Kota;

d. Pelaksanaan koordinasi dan kerja sama P4GN dengan instansi pemerintah terkait dan komponen masyarakat dalam wilayah Kabupaten/Kota;

e. Pelayanan administrasi BNNK/Kota; dan

f. Pelaksanaan evaluasi dan pelaporan BNNK/Kota.

Badan Narkotika Kabupaten Tapanuli Selatan, tertuang dalam Peraturan Kepala Badan Narkotika Nasional Nomor 3 Tahun 2015 tentang Pembentukan Badan Narkotika Propinsi dan Badan Narkotika Nasional Kabupaten/BNNK. Dalam peraturan tersebut dijelaskan bahwa tugas 
Badan Narkotika Nasional Kabupaten/Kota adalah membantu Badan Narkotika Nasional Provinsi/BNNP dan Pemerintah Kabupaten dalam hal:

a) Melakukan penyuluhan, pencegahan dan kegiatan operasi dalam upaya pemberantasan penyalahgunaan dan peredaran gelap narkotika, psikotropika, prekusor dan bahan adiktif lainnya di wilayah kabupten pemalang, dan mengacu pada ketenteuan perundangundangan.

b) Melakukan koordinasi pemanduan dan standar metode dalam upaya rehabilitasi terhadap korban penyalahgunaan narkotika, psikotropika, prekusor dan bahan adiktif lainnya, baik dari segi aspek sosial maupun medis untuk dijadikan acuan bagi lembaga / badanbadan resmi yang menyelenggarakan rehabilitasi terhadap korban penyalahgunaan narkotika, psikotropika, prekusor dan bahan adiktif lainnya.

c) Melaporkan Informasi kepada pemerintah mengenai pelaksanaan pemberantasan penyalahgunaan dan peredaran gelap narkotika, psikotropika, prekusor dan bahan adiktif lainnya di kabupaten Tapanuli Selatan.

d) Melaporkan hasil pelaksanaan kegiatan tersebut di atas kepada BNNP.

Berdasarkan uraian tugas BNN di atas, maka jelaslah bahwa BNK / BNN Kabupaten Tapanuli Selatan fungsinya berdasarkan pembidangannya sebagaimana berikut ini: a. Bidang Pencegahan dan Penegakan Hukum

b. Bidang Terapi dan Rehabilitasi.

c. Bidang Informatika

Badan Narkotika Nasioanal (BNN) Dalam Menjalankan Tugas dan Fungsinya tidak terlepas dari adanya hambatan yang dihadapi dan dicari upaya mengatasi hambatan tersebut. Adapun hambatan yang dihadapi oleh Badan Narkotika Nasioanal (BNN) dalam menjalankan tugas dan fungsinya, sebagaimana hasil wawancara penulis dengan pihak BNN Kabupaten Tapanuli Selatan pada Sub umum BNN Tapanuli Selatan, yaitu sebagai berikut:

1. Minimnya Personil yang Membidangi dalam penindakan.

2. Minimnya Peralatan atau fasilitas.

3. Kewenagaan Lebih besar diberikan Kepada Provinsi

Selain dari hamabatan di atas, Badan Narkotika Nasional Kabupaten Tapanuli Selatan juga menghadapi beberapa hambatan lain yang lebih berat dan sulit dilakukan untuk melaksanakan pemberantasan dalam penyalahgunaan narkotika, hambatan yang sering ditemui di lapangan yaitu sebagai berikut:

1. Faktor Iternal Pelaku

2. Faktor eksternal pelaku

\section{Kesimpulan}

1. Badan Narkotika Nasional dalam membantu Penegakan Hukum terhadap Penyalahgunaan Narkotika di Kabupaten Tapanuli Selatan telah 
berperan dengan baik sesuai tugas dan fungsinya, hal ini dibuktikan dengan data dan fakta hasil penelitian berupa kegiatan yang dilakukan di berbagai bidang yaitu:
a) Bidang Pencegahan dan Penegakan Hukum
b) Bidang Terapi dan Rehabilitasi .
c) Bidang Informatika

2. Adapun hambatan yang dihadapi Badan Narkotika Nasional (BNN) menjalankan tugas dan fungsinya dalam membantu Penegakan hukum terhadap penyalahgunaan Narkotika di Kabupaten Tapanuli selatan adalah sebagai berikut:

1. Minimnya Personil yang Membidangi dalam penindakan.

2. Minimnya Peralatan atau fasilitas

3. Kewenagaan Lebih besar diberikan Kepada Provinsi,

4. dan Faktor internal pelaku dan faktor eksternal pelaku

\section{Saran}

1. Hendaknya aparat penegak hukum lebih ketat mengawasi pengedaran Narkotika di wilayah Hukum Badan Narkotika Nasional dan resor Tapanuli Selatan, serta memberikan hukuman yang cukup berat sesuai dengan ancaman yang terdapat dalam undang-Undang Nomor 35 tahun 2009 tentang narkotika agar ada efek jera bagi pemakainya.

2. Badan Narkotika Nasional melalui penyuluhan hukumnya hendaknya membuat agenda kunjungan yang lebih terperinci ke daerah-daerah yang dianggap sebagai daerah rawan pengedaran Narkotika. Dan juga lembaga pendidikan. Khususunya tingkat Menegah dan sekolah lanjutan atas.

3. Bagi seluruh masyarakat/orang tua yang berada di Wilayah hukum Badan Narkotika Nasional Kabupaten Tapanuli Selatan dan Polres Tapsel, ikut serta berperan aktif dalam memerangi narkotika, terutama didalam keluarga kita sendiri agar keluarga kita terjauhi dari barang narkotika tersebut yang sangat merugikan generasi muda bangsa.

\section{Daftar Pustaka}

Agin Meonthe, Narmotika, Alkohol dan Permasalahannya. Jakarta : Yayasan Fomasi 1985

B. Simanjuntak, Pengantar Kriminologi חan Datnlngi Cncial, Tarsito, Bandung: 1998

B.Bosu, Penyalahgunaan Narkotika Dan Obat-obatan (Drags) Lainnya, Panitia Lustrum ke IV, Malang: 1974

B A Simanjuntak, Sadar Sebelum Terlambat. Medan: Monora. 1976

Gatot Supramono, Hukum Narkoba Indonesia, Jakarta : 2007

H.. Sumarno ma'sum, Penanggulangan Bahaya Narkotika Dan Ketergantungan Obat, Haji Masagung, Jakarta, 1987 
H. Hadari Nawawi,Metode

Penelitian, Raja Grafindo, Jakarta, 1990

Imade Wirarta,

MetodologiPpenelitian Sosial, Yokyakarat, Andi Offset, 2006

Kaelen, Pendidikan Pancasila. Yogyakarta: Pradigma, 2004

M. Ali, ProsedurPpenelitian. Bandung, Tarsito, 2006

Mas'un Sumarno. Penanggulangan Bahaya Narkotika dan Ketergantungan Obat. Jakarta, Haji Mas Agung. 1987

Moeljatno. Hukum Pidana. PT.Rineka Cipta,2006

MOH. HATTA, Beberapa Masalah Penegakan Hukum Pidana Umum \& Pidana Khusus, Liberty Yogyakarta, Yogyakarta : 2009

Majamal Abd. Hafid, Masalah Ganja Dan Morphine, F. A. Pustaka Progresif, Surabaya: 1980

Suharsimi Arikunto, Manajemen Penelitian, Jakarata, Rineka Cipta, 2010

Sugiono, Metode Penelitian, Rineka Cipta,2005

Sudaryono, Buku Pegangan Kulliah Hukum Pidana, Surakarta. Universitas Muhammadiyah Surakarta

Simons, Hukum Pidana, Rineka Cipta,2006

Undang-undang $\quad R I \quad$ Nomor 35 Tahun 2009 Tentang Narkotika
Keputusan Presiden Nomor 17 Tahun 2002 Tentang Badan Narkotika Nasional 